\author{
Krzysztof REJMAN ${ }^{1}$ \\ Grzegorz BŁAŻEJEWSKI ${ }^{2}$
}

\title{
REFLEKSJE NAD JAKOŚCIĄ ŻYCIA OSÓB NIEPEŁNOSPRAWNYCH W ASPEKCIE GLOBALIZACJI KULTURY
}

\begin{abstract}
Pozytywne skutki globalizacji kultury, to m.in. szerokie upowszechnianie najnowszych osiągnięć nauki i techniki wśród różnorodnych grup społecznych, w tym także tych zagrożonych marginalizacją, jaką są osoby z niepełnosprawnością. Korzyści jakich mogą one doświadczać, to nie tylko możliwość otrzymywania profesjonalnej, specjalistycznej opieki medycznej w ośrodkach zdrowia, gabinetach fizjoterapeutycznych, szpitalach, ale pełne uczestnictwo w życiu społecznym poprzez edukację, pracę zawodową oraz powszechne zwalczanie popularnych stereotypów dotyczących ich miejsca i roli w społeczeństwie. Globalizacja, mimo licznych negatywnych ocen jest szansą dla upowszechniania ideałów moralizmu i humanizmu chrześcijańskiego, zgodnie z którymi każdy człowiek, bez względu na swoją kondycję psychofizyczną stanowi istotę wyjątkową, której życie posiada szczególną wartość. Efektem globalizacji kultury jest także szybkie rozprzestrzenianie się wielu groźnych dla społeczeństw, w tym zwłaszcza dla osób z niepełnosprawnością zjawisk. Należą do nich m.in. nadmierne przywiązywanie wagi do osobistego wyglądu, kształtu sylwetki ciała, urody, ubioru, mody; lekceważenie ludzkiego cierpienia, zanikanie solidarności osób sprawnych i niepełnosprawnych w pokonywaniu codziennych wyzwań życiowych; utrzymywanie się w społeczeństwie krzywdzących osoby z niepełnosprawnością stereotypów, dominacja orientacji życiowej „mieć” nad orientacją „,być kimś”. Problemem i zarazem wyzwaniem wielu krajów na świecie jest bezrobocie i edukacja osób niepełnosprawnych. Mimo podejmowanych przez rządy państw wysiłków sytuacja nie jest jeszcze zadawalająca. Osoby niepełnosprawne należą w znacznej większości do najsłabiej wykształconej części społeczeństwa, dlatego w dobie powszechnej informatyzacji i wysoko zaawansowanych technologii mają nikłe szanse na rynku pracy. Bezrobocie jest istotną przyczyną pogarszania się jakości ich życia, prowadzi do życia w ubóstwie.
\end{abstract}

Słowa kluczowe: jakość życia, niepełnosprawność, społeczeństwo, globalizacja.

\footnotetext{
${ }^{1}$ Dr hab. Krzysztof Rejman, prof. PRz, Katedra Nauk Humanistycznych, Politechnika Rzeszowska (autor korespondencyjny); e-mail: krejman@ poczta.onet.pl

Krzysztof Rejman, DSc, PhD, Department of Humanities, Faculty of Management, Rzeszow University of Technology, Poland - Rzeszow, corresponding author; e-mail: krejman@ poczta.onet.pl

${ }^{2}$ Dr Grzegorz Błażejewski, Krakowska Akademia im. Andrzeja Frycza Modrzewskiego, ul. Gustawa Herlinga-Grudzińskiego 1, 30-705 Kraków.

Grzegorz Błażejewski, PhD, Andrzej Frycz Modrzewski, Krakow University, ul. Gustawa Herlinga-Grudzińskiego 1, 30-705 Krakow.
} 


\section{WPROWADZENIE}

Ludzkie życie stanowiące fenomen na skalę kosmiczną jest tą szczególną dla nas wartością, której w różnych kulturach nadaje się zmienna rangę. Może być bowiem traktowane jak sacrum, bądź jak rynkowy towar mający w zależności od zmiennego popytu i podaży określoną cenę.

W czasach współczesnych - postmodernizmu - mamy do czynienia z rozchwianiem systemu wartości, powszechnym kryzysem autorytetów, zagubieniem człowieka wśród nawału informacji - szumu medialnego i rozmaitych koncepcji tego ,jak żyć?”. Tak zwane „wielkie narracje” obiecują nadal powszechne szczęście, dobrobyt, bezpieczeństwo nakłaniając do popierania lansowanych ideologii i doktryn. Troska o jakość naszego życia jest kluczowym hasłem wszystkich zainteresowanych zdobyciem władzy, od najniższych do najwyższych szczebli.

\section{WSPÓŁCZESNE INTERPRETACJE JAKOŚCI ŻYCIA}

Pojęcie ,jakość życia” ma charakter względny, dlatego używając go należy każdorazowo podać układ odniesienia by sens jego był dla każdego zrozumiały. Według definicji encyklopedii multimedialnej ,jakość życia” „to stopień zaspokojenia potrzeb materialnych i niematerialnych jednostek, rodzin i zbiorowości; pojęcie stosowane w polityce społecznej; badania nad jakością życia dotyczą: potrzeb zaspokajanych przez spożycie dóbr i usług (poziom życia, stopa życiowa), treści stosunków i więzi społecznych (np. poziom kooperacji i integracji społecznych, nasilenie konfliktów jednostkowych i zbiorowych); jakość życia określają wskaźniki obiektywne (ilościowe i jakościowe, rzeczowe i wartościowe) oraz subiektywne (np. stopień zadowolenia z warunków życiowych"3.

Według Waldemara Furmanka, analiza literatury naukowej, poświęconej problematyce jakości życia pozwala wyszczególnić cztery podejścia definicyjne. „Obejmują one definicje implikacyjne, zakładające, że normalizacja warunków życia oznacza lepszą jakość życia; definicje operacyjne, określające warunki, jakie muszą być spełnione, aby zmieniła się jakość życia; definicje aksjologiczne, nawiązujące do przekonań i systemów wartości jednostek, oraz inne definicje o bardzo zróżnicowanym charakterze, przyjmujące za wskaźniki empirycznej jakości życia bardzo różne zjawiska ${ }^{4}$.

Zdaniem Michała Hellera: „odpowiedź na pytanie »Jak żyć? « pisze się całym życiem. A gdy już wreszcie odpowiedź zostanie poznana, będzie za późno, żeby samemu z niej skorzystać i komuś ją przekazać. Zresztą i tak odpowiedzi na pytanie »Jak żyć? «nikt by od nas nie przyjął. Każdy musi swoje życie przeżyć sam i znaleźć swoją odpowiedź. (...) Można by się zastanawiać, czy pod tym względem jest jakaś różnica między wierzącym a niewierzącym. Owszem, jest. Niewierzący sądzi, że jeżeli przegra życie, to przegra życie i nic więcej. wierzący wie, że życia przegrać nie może, bo nie o samo ziemskie życie sprawa się rozgrywa. I nie jest to tylko kwestia przekonań: że ten sądzi tak, a tamten inaczej. Rzeczywistość nie zależy od czyichś przekonań"5.

„(...) Jeżeli pytanie jest za trudne, niekiedy skuteczniej można przybliżyć się do odpowiedzi, gdy postawi się pytanie przeciwne. Jak żyć? Może więc łatwiej: Jak nie należy żyć?

\footnotetext{
3 W. Furmanek, Zarys humanistycznej teorii pracy, Warszawa 2006, s. 160.

${ }^{4}$ Ibidem, s. 161.

5 M. Heller, Wszechświat jest tylko drogą. Kosmiczne rekolekcje, Kraków 2012, s. 138.
} 
Odpowiedź na to drugie pytanie może być ważna, bo mówi, czego w życiu nie należy czynić. A to już duża część SZTUKI ŻYCIA"6.

Ludzkie życie oceniane bywa w bardzo różnych aspektach, przy użyciu rozmaitych metod, technik, narzędzi i skal pomiarowych. W naukowym podejściu podejmuje się liczne próby, by ocena ta była jak najbardziej obiektywna i dlatego wielu autorów sporządza listy wskaźników definicyjnych i interferencyjnych, umożliwiających komparatystyczne interpretacje uzyskiwanych wyników.

Jakość życia jest nie tylko interesującym od kilkudziesięciu lat wiele nauk przedmiotem badań, ale przede wszystkim tematem powszechnych osobistych refleksji, źródłem emocji, wyzwaniem i motywatorem do ustawicznego wysiłku każdego człowieka. Fenomenologiczne podejście do oceny jakości życia sprawia, że jest ona często zmienna w zależności od rozwoju osobistych potrzeb różnej natury, np. społecznych, edukacyjnych, religijnych, zdrowotnych. Są one wynikiem zarówno zmian zachodzących w środowisku życia człowieka, jak też jego intelektualnego, psychicznego i duchowego rozwoju - ewolucji osobistego systemu wartości, stanowiących regulator codziennego postępowania każdej osoby.

Na temat wartości, a więc tego wszystkiego, co człowiek uznaje za ważne, godne poświęcenia czasu i wysiłku - czasami zdrowia, a nawet życia - wypowiada się wielu autorów uznawanych powszechnie za autorytety moralne i naukowe. W literaturze znaleźć można szereg ich klasyfikacji, taksonomii i definicji. Nie brak też polemik na temat ich charakteru - stałości, bądź zmienności czy relatywizmu, a także źródeł - kultury materialnej i symbolicznej, bądź metafizycznego objawienia.

Wraz z dynamicznym rozwojem naukowo-technicznym zmieniają się warunki życia ludzi na całym świecie, a poprzez to także ich życiowe potrzeby i aspiracje. Skutkiem postępującej globalizacji kultury jest m.in. powszechny dostęp do informacji o warunkach życia na całym świecie, możliwościach nowoczesnej techniki w dziedzinie np. transportu, komunikacji, medycyny. Dzięki wiedzy coraz szersze kręgi społeczne dążą do osiągnięcia możliwie szerokich, różnorodnych korzyści w dziedzinie ograniczania wysiłku w pracy zawodowej, zwiększenia jej efektywności - opłacalności, podniesienia standardów mieszkaniowych, spędzania czasu wolnego, ochrony zdrowia - profilaktyki i leczenia.

Upowszechnia się model życia nastawionego głównie na gromadzenie wszelkich dóbr materialnych, konsumpcję dorobku kulturowego, hedonizmu. Względy ekonomiczne skłaniają obywateli państw słabo rozwiniętych do masowej emigracji do krajów zamożnych i zaniechania jakichkolwiek wysiłków na rzecz rozwoju własnych ojczyzn. W powszechnym wyścigu do zdobywania władzy, wpływów, pieniędzy szanse na sukces mają nieliczni - nie zawsze najzdolniejsi, prawi i szlachetni. Nie ma w nim miejsca dla osób, które z różnych względów nie posiadają wystarczającej ,siły przebicia się”, uzależnionych od innych ze względu np. na stan zdrowia, wiek, miejsce zamieszkania, możliwości intelektualne, cechy psychiczne.

\section{ZAGROŻENIA JAKOŚCI ŻYCIA OSÓB Z NIEPEŁNOSPRAWNOŚCIĄ}

W globalizującym się społeczeństwie na osoby z niepełnosprawnością czyha wiele zagrożeń, z racji tego, że coraz częściej do głosu dochodzą zwolennicy poglądów redukcjonistycznych, traktujących wartość życia podobnie jak rynkową wartość towaru, która zależy

${ }^{6}$ Ibidem, s. 139. 
od poziomu popytu i podaży w określonym miejscu i czasie. Tak zwana nowa etyka, promowana m.in. przez P. Singera i jego zwolenników, stara się usprawiedliwić to, co Jan Paweł II określił mianem ,cywilizacji śmierci”, w której zupełnie ignoruje się ludzka godność, wyjątkowość, szczególną wartość życia. Pod znakiem zapytania stawia potrzebę i zasadność ponoszenia kosztów ratowania czy przedłużania życia osób nieuleczalnie chorych, kalekich, niedołężnych - niepełnosprawnych. niepełnosprawność w jej aspekcie stanowi dla człowieka nią dotkniętego wyrok skazujący go na marginalizację społeczną i wykluczęnie z życia zawodowego, rodzinnego; pozbawienie części niezbywalnych ludzkich praw posiadania rodziny, pracy, uczestniczenia w kulturze. Wywołuje też wiele kontrowersji dotyczących posiadania przez osoby z niepełnosprawnością intelektualną, bądź wrodzonymi wadami genetycznymi potomstwa.

Prawo do życia w zasadzie przyznaje się tylko osobnikom najsilniejszym, sprawnym pod każdym względem, wzorem naturalnej selekcji jaka od wieków dokonuje się w świecie przyrody. Gdy Natura popełnia błąd, to sama go eliminuje poprzez śmierć uszkodzonego wadliwego - organizmu, by nie powielać go w kolejnych pokoleniach.

Szczególnym zagrożeniem dla jakości życia osób z niepełnosprawnością jest zjawisko określane w literaturze naukowej mianem ,somatocentryzmu”. Jego istotą jest koncentrowanie uwagi i wysiłku na wyglądzie zewnętrznym - zgrabnej i szczupłej sylwetce, idealnych proporcjach części ciała, gustownych makijażach, tatuażach, ozdobach, stroju, fryzurze, wysokiej sprawności fizycznej. Wygląd zewnętrzny stanowi przedmiot szczególnej, a czasami nawet jedynej troski osoby skłonnej ponosić nieraz ogromne wyrzeczenia, nakłady czasu i pieniędzy dla uzyskania satysfakcjonującego ja efektu.

Somatocentrycy uważają, że trzeba bardzo dbać o osobisty wygląd, bo to on głównie przesądza o zajmowanej pozycji społecznej. Odpowiedni wygląd jest w zasadzie tym, co gwarantuje człowiekowi sukces, dobre samopoczucie, uznanie w środowisku społecznym.

W świecie globalnej kultury ,istotna rolę w kształtowaniu obowiązujących standardów wyglądu ludzkiego ciała, idealnych wzorców kobiecości i męskości pełnią współczesne media, przekazujące standardy popkultury. Doniesienia prasowe, filmy, a także reklamy kreują cielesne mity i ideały - gloryfikują urodę, kult ciała perfekcyjnego, zdrowego i wiecznie młodego"

Zjawisko dostosowywania osobistego wyglądu do społecznych oczekiwań, popularnych, akceptowanych masowo wzorców prowadzi do ciągłego porównywania siebie z lansowanymi głównie w reklamach modelami. Jak ocenia S. Kowalik, „współczesny rozwój kultury doprowadził do sytuacji, w której ciało zaczęto traktować jako najważniejszy emblemat, za pomocą którego człowiek może dookreślić własną indywidualność"8.

Zdaniem Doroty Kubackiej-Jasieckiej: ,,współczesne kulturowo-społeczne trendy przywiązują coraz większą wagę do ludzkiego ciała i jego wyglądu, można powiedzieć, że wręcz go gloryfikują. Upowszechnienie wartości ciała idealnego, niezmienne sprawnego,

\footnotetext{
${ }^{7}$ M. Jakubczak, Cielesna tożsamość człowieka wspótczesnego. „Sztuka Leczenia”, 4 (1999), s.83-89; cyt. za Psychologia zdrowia w poszukiwaniu pozytywnych inspiracji, red. I. Heszen, J. Życińska, Warszawa 2008, s. 188.

${ }^{8}$ S. Kowalik, Ja-cielesne - próba nowego spojrzenia. Polskie Forum Psychologiczne, 8 (2003), 1-2, s. 5-29; cyt. za Heszen I, Życińska J. (red.), Psychologia zdrowia w poszukiwaniu pozytywnych inspiracji, Wydawnictwo Szkoły Wyższej Psychologii Społecznej „Academica”, Warszawa 2008, s. 187.
} 
urodziwego i młodzieńczego budzi obawy o psychologiczne konsekwencje tego stanu rze-

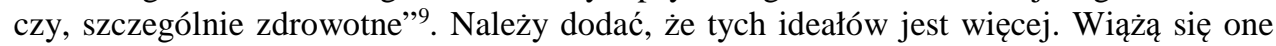
m.in. z jakością życia osób niepełnosprawnych, skazywanych niejako automatycznie, z racji swoich ułomności, kalectwa, na marginalizację, bądź nawet całkowite wykluczenie z pełni życia społecznego - funkcjonowanie na jego peryferiach, bez szans na pełne, twórcze uczestnictwo w kulturze.

W społeczeństwach somatocentryków osoby z niepełnosprawnością doświadczają stygmatyzacji i alienacji ze środowisk pracy, zamieszkania, a często także rodzinnych. Konsekwencją tego jest brak nadziei motywującej ich do aktywności w poszukiwaniu możliwości realizacji rozmaitych osobistych celów - brak poczucia sensu cierpienia i życia.

\section{WARTOŚCI CHRZEŚCIJAŃSKIE A NIEPEŁNOSPRAWNOŚĆ}

Współczesny człowiek bardzo często stara się przemilczać, zagłuszać, wypierać ze świadomości problemy cierpienia, kalectwa, nieuleczalnej choroby, śmierci. Jednakże, jak trafnie zauważa Adam Podolski: „,cierpienia nie da się przezwyciężyć. Towarzyszyło ono ludzkiej egzystencji i nadal będzie od niej nieodłączne w doczesnym życiu - »cierpienie zdaje się przynależeć do transcendencji człowieka« [SD 2]. Cierpi już dziecko, gdy przychodzi na świat, zmieniając środowisko swego bytowania, cierpi młodzież z powodu ograniczonych możliwości i nieograniczonych pragnień, cierpi człowiek dojrzały z powodu wielu porażek, niesprawiedliwości, przeżywanych problemów i doznawanego zła, cierpi człowiek konający w bólu i ze świadomości, że bramy śmierci przekracza w samotności"10.

Religia chrześcijańska, której integrujące ludzkość wpływy nie maleją, dzięki m.in. wysiłkom św. Jana Pawła II, szczególną opieką nakazuje otaczać każdego cierpiącego, potrzebującego pomocy i wsparcia człowieka. W ocenie cytowanego autora ,solidarność z cierpiącymi i miłość świadczona wobec nich jest fundamentalną opcją chrześcijaństwa. Dać siebie w bezinteresownym darze dla innych to synteza chrześcijańskiej antropologii [por. SD 28] i najdoskonalsza ekspresja ludzkiego powołania, albowiem »człowiek [...] nie może odnaleźć siebie w pełni inaczej, jak tylko poprzez bezinteresowny dar z siebie samego« [KDK 24]. Ewangeliczna przypowieść o miłosiernym Samarytaninie (Łk 10, 3-37) stanowi poglądową lekcję postawy, jaką chrześcijanin powinien zająć względem cierpiącego człowieka"l1.

Można odnieść ją także do każdej osoby z niepełnosprawnością fizyczną czy intelektualną. Postawa ta wymaga by:

- ,zatrzymać się z gotowością służby - nie z ciekawości (»miłosiernym Samarytaninem jest każdy człowiek, który zatrzymuje się przy cierpieniu drugiego człowieka, jakiekolwiek by ono było« - SD 28);

- wzruszyć się (»miłosiernym Samarytaninem jest każdy człowiek wrażliwy na cudze cierpienie, człowiek, który wzrusza się nieszczęściem bliźniego« - SD 28);

\footnotetext{
${ }^{9}$ D. Kubacka-Jasiecka, Ja cielesne i problematyka identyfikacji z ciatem $w$ kontekście wartości wspótczesnej kultury i zdrowia [w:] Psychologia zdrowia..., s. 185.

10 A. Podolski, Przywrócić sens cierpienia i godność cierpiącego [w:] Święty Jan Pawet II-pierwszy doktor honoris causa Uniwersytetu Rzeszowskiego, red. ks. S. Nabywaniec, Rzeszów 2015, s. 103.

11 Ibidem, s. 118
} 
- współczuć (»jeżeli Chrystus, znawca wnętrza ludzkiego, podkreśla owo wzruszenie, to znaczy, że jest ono również ważne dla całej naszej postawy wobec cudzego cierpienia. Trzeba więc w sobie pielęgnować ową wrażliwość serca, która świadczy o współczuciu z cierpiącym. Czasem owo współczucie pozostaje jedynym, lub głównym wyrazem naszej miłości i solidarności z cierpiącym człowiekiem « SD 28);

- okazać możliwie skuteczną pomoc polegającą na darze z siebie samego, połączoną z wykorzystaniem posiadanych dóbr materialnych (»Miłosiernym Samarytaninem jest więc ostatecznie ten, kto świadczy pomoc w cierpieniu (...), o ile możliwości, skuteczną. W tę pomoc wkłada swoje serce, nie żałuje również środków materialnych. Można powiedzieć, że daje siebie, swoje własne ,ja” dla drugiego« SD 28)" $" 12$

Kultura europejska rozwijana na kanwie wartości chrześcijańskich, mimo pojawiających się symptomów ich kryzysu, wywiera nadal silny wpływ na kreowanie polityki społecznej wobec osób z niepełnosprawnością w wielu krajach Unii Europejskiej, a także na świecie. W ostatnim ćwierćwieczu zainteresowanie jakością ich życia ustawicznie pogłębia się, czego dowodem są liczne akty prawne mające ułatwić im integrację ze społeczeństwem. Dotyczą one wielu dziedzin codziennej aktywności człowieka, a m.in. nauki, pracy zawodowej, życia rodzinnego, ochrony zdrowia. Gwarantują równość w korzystaniu z pakietu podstawowych praw, zapisanych w Powszechnej Deklaracji Praw Człowieka ONZ z 1948 roku, oraz Deklaracji Praw Osób Niepełnosprawnych z 1975 roku.

Do pozytywnych zmian w stereotypowym postrzeganiu roli i miejsca osób z niepełnosprawności należy zaliczyć objęcie ich globalną ideą olimpizmu i organizację igrzysk paraolimpijskich. Sfera kultury, która od lat nie była kojarzona z niepełnosprawnością, stała się dostępna i promowana wśród osób nią dotkniętych.

\section{SPOŁECZNO-EKONOMICZNE ASPEKTY NIEPEŁNOSPRAWNOŚCI}

Rozważając jakość życia w aspekcie społeczno-ekonomicznym, należy oceniać takie konstytutywne jego cechy, jak praca zawodowa, dochody, możliwości wszechstronnego rozwoju, a więc warunki ustawicznej edukacji, sytuację w dziedzinie możliwości usamodzielnienia się i zakładania własnych rodzin. Mimo sprzyjającego klimatu dla aktywizacji zawodowej osób niepełnosprawnych nadal pozostaje jeszcze w tej kwestii wiele do zrobienia.

Jak wskazują dane statystyczne, są oni grupą społeczną stosunkowo słabo wykształconą, a przez to także posiadającą małe szanse na znalezienie dobrze płatnej pracy. Warto podkreślić, że niepełnosprawność zwykle generuje znaczne potrzeby związane z utrzymaniem kondycji psychofizycznej, których zaspokajanie, nawet na podstawowym poziomie wymaga wysokich nakładów finansowych. Mimo rozmaitych świadczeń ze strony państwa i ulg w opłatach, wysokie zarobki są tu jak najbardziej pożądane.

Wbrew rozmaitym stereotypom, osoba z niepełnosprawnością nie jest skazana na wykonywanie bardzo prostych, lekkich prac, zwykle nisko opłacanych. Dysfunkcje fizyczne, np. narządów ruchu, nie obniżają potencjału i możliwości intelektualnych osoby, która z powodzeniem może podejmować nawet te prace, gdzie niezbędne są wysokie kwalifi-

\footnotetext{
12 Ibidem, s. 118 .
} 
kacje. Postęp naukowo-techniczny sprawia m.in. zmianę charakteru pracy. Coraz więcej funkcji ludzkich mięśni przejmują urządzenia całkowicie zautomatyzowane, sterowane programami komputerowymi, a nadzorującemu ich człowiekowi pozostaje jedynie śledzenie zachowania rozmaitych wskaźników informujących o jakości przebiegu skomplikowanego procesu.

Automatyzacja i powszechna informatyzacja sprawiają, że rośnie popyt na pracowników nie tyle silnych i sprawnych fizycznie, lecz posiadających coraz bardziej specjalistyczne umiejętności w dziedzinie projektowania, konstruowania i wykorzystywania programów komputerowych.

Zważywszy, że w Polsce 16\% osób z niepełnosprawności znajduje się w wieku 16-65 lat, a więc mogących zasilać rynek pracy stosowanie do swoich możliwości, uzasadnionym jest inwestowanie w ich permanentną edukację, motywowanie do aktywności zawodowej i zapobieganie tym samym tzw. wyuczonej bezradności. Termin ten został wprowadzony przez V. Thorseina (1857-1929), ekonomistę i filozofa amerykańskiego, dla oznaczenia braku lub ograniczonej zdolności do odpowiedniego reagowania w nowych, zmieniających się sytuacjach życiowych i zawodowych. Teoria wyuczonej bezradności zakłada, że ludzie w sytuacji trudnej poddają się bezradności, czyli zatracają dążenie do roztoczenia kontroli (samokontroli) nad sytuacją, by dojść do przeświadczenia, że w tej sytuacji nic nie da się zrobić $^{13}$.

Współcześnie bezradność może rozwijać się nie tylko u ludzi marginalizowanych społecznie - chorych, uzależnionych, bezdomnych, lecz również wśród tych, którzy nie nadążają z rozmaitych przyczyn za postępem technicznym i dynamicznymi zmianami życia społecznego. Wiele naukowych i literackich dzieł poświęcono roli i apoteozie pracy człowieka. W zgodnej ocenie wielu autorytetów, brak pracy - bezrobocie, które na trwale wpisało się do współczesnej rodzimej i światowej gospodarki, to nie tylko problem ekonomiczny i społeczny, ale osobisty dramat każdej dotkniętej nim osoby. Brak pracy dla osoby z określoną niepełnosprawnością utwierdza ją w przekonaniu, że społeczeństwo jej nie potrzebuje - to społeczeństwo, które tak bardzo pozycja człowieka, prestiż, autorytet uzależnione SA od uzyskiwanych dochodów, stanowisk osiągnięć i wpływów.

Zdaniem Waldemara Furmanka: „każda postać bezrobocia uderza w osobową godność człowieka. W odbiorze społecznym bezrobocie jest widocznym znakiem małej wartości człowieka, niewystarczalności jego potencjału psychicznego, zależności od anonimowych mechanizmów społeczno-gospodarczych, wyrazem społecznej degradacji"14.

Liczne, groźne dla jakości życia każdej osoby skutki bezrobocia, a zwłaszcza, człowieka borykającego się z dysfunkcjami swego organizmu, cytowany autor ujmuje syntetycznie: „bezrobocie poniża człowieka w jego własnych oczach, wywołuje poczucie bycia niepotrzebnym i odrzuconym przez społeczeństwo. Stałe lub długotrwałe bezrobocie grozi deformacją osobowości człowieka. Niejednokrotnie wpływa zdecydowanie na zjawiska życia rodzinnego i małżeńskiego, powodując rozmaite negatywne konsekwencje. Oprócz obniżenia się dochodów i poziomu życia rodziny bezrobocie wzmaga niepokój o jutro, wywołuje stres u członków rodziny, potęguje konflikty, popycha w stronę rozmaitych uzależnień, kształtuje lub wzmaga postawy aspołeczne, rozwija poczucie niskiej wartości i obniża

\footnotetext{
${ }^{13}$ W. Furmanek, Zarys humanistycznej teorii pracy (nowe horyzonty pedagogiki pracy), Warszawa 2006, s. 234.

14 Ibidem, s. 278.
} 
twórcze możliwości człowieka. W konsekwencji bezrobocie przyczynia się do dezintegracji rodziny, a często nawet do jej rozpadu"15.

$\mathrm{W}$ miarę postępu społecznego, rozwoju nauki i techniki, a zwłaszcza możliwości w dziedzinie ochrony i przywracania utraconego zdrowia - rehabilitacji - aspiracje wielu osób na pełniejsze uczestnictwo w kulturze znacząco wzrastają. Nie wystarcza im już tylko śledzenie bieżących wydarzeń, np. za pośrednictwem mediów, ale pragną a nich osobiście uczestniczyć - wpływać na ich kształt i przebieg. Trudnym do przecenienia wsparciem w tych dążeniach stał się w ostatnich latach Internet. Jest już nie tylko źródłem bogatych informacji o świecie, ale narzędziem wszechstronnych kontaktów międzyludzkich. Dzięki niemu, bez względu na dzielące użytkowników odległości w przestrzeni, możliwa stała się praktycznie nieograniczona wymiana poglądów, opinii, pomysłów, idei; nauka, zdobywanie kwalifikacji, praca; kontakty z organizacjami, instytucjami, załatwianie różnorodnych życiowych spraw.

Dla ludzi, zwłaszcza młodych, aktywne życie ,towarzyskie” ze wszystkimi jego rodzajami i cechami przeniosło się z rzeczywistości realnej do wirtualnej, gdzie kontakty face to face nie są wymagane i konieczne. Na portalach społecznościowych dokonywane są autoprezentacje, zawierane są znajomości, nawiązywane kontakty, wymieniane oceny, zawiązywane rozmaite stowarzyszenia, inicjowane i organizowane liczne społeczne akcje.

Mimo oczywistych zagrożeń jakie niesie anonimowość osób korzystających z nich, pełnią one szczególnie ważną rolę we włączaniu osób z ograniczeniami mobilności do pełni życia kulturalno-społecznego, a także gospodarczego i politycznego. Należy jednak dodać, że mimo niezaprzeczalnych walorów, życie w przestrzeni wirtualnej nie może całkowicie zastąpić tradycyjnych, osobistych kontaktów międzyludzkich, doświadczania pozytywnych emocji w bezpośrednich kontaktach z osobami, które poświęcają drugim swój czas, zainteresowanie, życzliwą uwagę.

Problemy jakości życia osób dotkniętych niepełnosprawnością stały się również przedmiotem pogłębionych badań i refleksji naukowych m.in. pedagogiki, pedagogiki specjalnej, psychologii zdrowia, nauk o zdrowiu czy nauk o kulturze fizycznej, fizjoterapii. W ramach działań umożliwiających im pełniejsze uczestnictwo w kulturze stworzono warunki do rozwoju takich jego form, jak sport, rekreacja ruchowa, turystyka. Przystosowano wiele obiektów użyteczności publicznej, a także szlaków i tras turystycznych do specjalnych potrzeb osób poruszających się na wózkach inwalidzkich, o kulach, niewidomych, głuchych.

Budującym przykładem troski o jakość życia osób z niepełnosprawnością jest m.in. realizacja programu „Tatry bez barier”, dzięki któremu mają one od kilku lat możliwość dotarcia do najpiękniejszych górskich zakątków na terenie Polski i Słowacji. Przykładów takich inicjatyw z ostatnich lat można by mnożyć - nie tylko w naszym kraju, ale w Europie i na całym świecie.

\section{DWA OBLICZA GLOBALIZACJI}

Polska należy już dzisiaj do krajów, które podejmują wiele szeroko zakrojonych działań na rzecz wyrównywania szans osób z niepełnosprawnością w dostępie do wszystkich dziedzin kultury - korzystania z dorobku nauk, techniki, kontaktów ze sztuką, podejmowania działalności zawodowej, ustawicznego kształcenia się przez całe życie, rozwijania osobistych pasji, zainteresowań i talentów.

\footnotetext{
15 Ibidem, s. 279.
} 
Grupa osób, do niedawna marginalizowanych, a nawet wykluczanych z pełni życia społecznego, dzisiaj dzięki postępowi technicznemu, demokratyzacji życia, a także postępującej jego humanizacji staje się coraz mocniej zintegrowana ze społeczeństwem, przez co zyskuje szanse na twórcze pomnażanie jego kulturowego dorobku, a nie jedynie bierną konsumpcję rozmaitych, powszechnie dostępnych dóbr.

W obiegowych opiniach jakość życia odnoszona jest zwykle do kilku dziedzin ludzkiej aktywności. Dotyczy najczęściej życia rodzinnego, zawodowego, społecznego, sposobu spędzania czasu wolnego, zdobywanego wykształcenia, uzyskiwanych dochodów. Rozważając ją zawsze uwzględnia się szeroki kontekst obejmujący lokalne warunki życia ludzi, a więc np. sytuację gospodarczo-polityczną kraju zamieszkania, jego historię, tradycje, poziom kultury i nauki, dominującą religię, ustrój, strukturę narodową, położenie geograficzne. Często stanowi układ odniesienie dla ocena jakości życia, która zawsze pozostaje względną - uwzględniająca bowiem lokalną skalę możliwości i potrzeb społecznych mniej lub bardziej uświadamianych poszczególnym osobom.

Globalizacja, czy jak często określa się to zjawisko, tzw. amerykanizacja kultury, na całym świecie sprawia, że konteksty wielu zjawisk społecznych zachodzących na skalę lokalną, konsekwentnie od dziesiątków lat upodabniają się do siebie. Telewizja satelitarna oraz Internet, zanikanie wszelkiego rodzaju barier komunikacyjnych, swobodny przepływ towarów, usług, kapitału i ludzi sprawiają, że w rozprzestrzeniającej się globalnej wiosce obowiązują powszechnie określone mody, style, reguły życia, konsumpcji, postępowania, uczestnictwa w kulturze. Zacierają się różnice, zanikają tradycje, giną języki mniejszości, a ich miejsce zajmują ponadnarodowe, ogólnie akceptowane wartości.

Globalizacja ma dwa oblicza. Z jednej strony stanowi poważne zagrożenie dla indywidualności kulturowej narodów mniejszych, państw słabszych gospodarczo, z drugiej jednak przyczynia się do upowszechnienia szeregu najnowocześniejszych osiągnięć naukowotechnicznych na skalę ogólnoświatową. Z perspektywy zaspokojenia życiowych potrzeb osób niepełnosprawnych w różnych krajach można mieć uzasadnioną nadzieję, że będzie przyczyniać się ona do ustawicznego zwiększania szans na pełną ich realizację. W warunkach pokojowego współistnienia, poszanowania suwerenności państw, narodów, współczesne zdobycze nauki i techniki mają pełne szanse na to by stać się ogólnoludzką własnością, m.in. poprzez powszechny dostęp o możliwości wykorzystania w wielu dziedzinach życia.

Osoby niepełnosprawne ogromne nadzieje wiążą z rozwojem nauk medycznych i przemysłu pracującego na rzecz ochrony, ratowania i przywracania zdrowia oraz wszelkich udogodnień dla osób dotkniętych chorobą bądź kalectwem. Coraz więcej chorób zaliczanych od wielu lat do nieuleczalnych, śmiertelnych, dzięki naukowemu i technicznemu postępowi udaje się skutecznie leczyć. Czas, jaki upływa od dokonania odkrycia naukowego czy wynalazku, do chwili wykorzystania go w praktyce staje się coraz krótszy. To już nie dziesiątki lat prób i eksperymentów, ale niejednokrotnie tylko miesiące. Dla poszukujących pomocy $\mathrm{w}$ walce $\mathrm{z}$ chorobą i niepełnosprawnością istotną jest informacja o tym, gdzie na świecie już wynaleziono właściwy lek, opracowano stosowną terapię, czy wykonuje się skuteczne zabiegi przywracające utracone zdrowie.

W tzw. Czwartej (według Tofflera) fali rozwoju cywilizacji, informacja stanowi kluczową wartość dla każdego człowieka - uczącego się, pracującego, poszukującego swego miejsca w życiu, dążącego do zaspokojenia rozmaitych potrzeb niezależnie od kondycji psychofizycznej. Dążenie do szybkiego uzyskiwania rzetelnych informacji doprowadziło do rozwoju globalnej sieci internetowej, bez której trudno wyobrazić sobie funkcjonowanie ludzkich zbiorowości na całym świecie. 
Globalizacja kultury jest konsekwencją postępu naukowo-technicznego, ale również jednym z istotnych czynników przyspieszających i intensyfikujących ten postęp. Zjawiska tego nie można w żaden sposób zahamować, mimo że nie w każdej dziedzinie życia przynosi ono oczekiwane, zadawalające efekty.

Podsumowując dokonania ubiegłego wieku, Waldemar Łysiak pisze: ,postęp czyniący człowieka lepszym i szczęśliwszym, skutecznie rozwiązujący każdy problem, jaki staje przed ludzkością, spełniający marzenia i urzeczywistniający dążenia, słowem budujący przyzwoity świat - zyskał rangę kultową, rangę głównego aksjomatu dziesięciu dekad kończących drugie tysiąclecie naszej ery. U kresu ostatniej dekady możemy sporządzać bilans. Wynik jest koszmarem - postęp okłamał ludzkość"16.

Zgodnie z powszechną nadzieją ma on bowiem przybliżać każdego człowieka do spełnienia marzeń, ambicji, uczynienia go szczęśliwszym. Szczególne nadzieje pokładają w nim osoby chore, stare, dotknięte niepełnosprawnością, uzależnione od pomocy i wsparcia innych. To, by mogły być one spełnione zależy dzisiaj w decydującej mierze od barier mentalnych tkwiących w przesądach, stereotypach, niesprawiedliwości społecznej akceptowanych w wielu środowiskach zdominowanych przez ambicje posiadania coraz większej władzy, wpływów, bogactwa.

Postęp naukowo-techniczny nie przekłada się - nie idzie w parze - z postępem moralnym ludzkości. To właśnie dlatego może stanowić coraz większe zagrożenie dla jakości życia, przyczyniając się do rozrostu grup osób marginalizowanych i wykluczonych społecznie. „(...) Między człowiekiem a postępem nie ma bezkarnych interesów. Za każdą korzyść trzeba gorzko płacić. I jakże często przepłacać! Słowem: tracić, ujmować, deprecjonować cywilizacyjnie. Lub wątpliwie zyskiwać - stać przy pozorach ruchu"17.

Osób z niepełnosprawnością przybywa na całym świecie z roku na rok. Przyczyn tego zjawiska jest kilka. Należą do nich wady genetyczne powodowane coraz większym skażeniem środowiska, wypadku komunikacyjne oraz liczne zbrojne konflikty ciągnące się latami bez szans na rozwiązanie.

Nie wszędzie szanse osób niepełnosprawnych na godne życie są jednakowe. Najlepsza sytuacja pod względem dbałości o ich los panuje w państwach Unii Europejskiej, najgorsza w krajach trzeciego Świata, a zwłaszcza w rejonach objętych działaniami militarnymi, czy dotykanych rozmaitymi przyrodniczymi kataklizmami.

Podobnie jak ma to miejsce wśród pełnosprawnej części populacji, jakość życia osób z niepełnosprawnością jest bardzo zróżnicowana w zależności od panujących w danym rejonie świata warunków gospodarczo-politycznych, poziomu rozwoju kultury, a także warunków naturalnych, tradycji historycznych, uwarunkowań światopoglądowych. Chrześcijańskie korzenie cywilizacji europejskiej sprawiają, że ideały moralizmu i humanizmu mimo rozmaitych ,zakłóceń lokalnych” - powszechnie są nadal obecne w życiu zdecydowanej większości Europejczyków. Stąd, jak można domniemywać, biorą się liczne inicjatywy dotyczące integrowania, włączania, aktywizacji - uczestniczenia w pełni życia społecznego - osób o specjalnych potrzebach, zagrożonych marginalizacją z racji swojej kondycji psychofizycznej. Jakość ich życia określana przez warunki umożliwiające edukację zgodną z aspiracjami, potrzebami i możliwościami, pracę zawodową, życie rodzinne, aktywność społeczną i polityczną, uczestnictwo w kulturze, stanowi wizytówkę każdego

\footnotetext{
16 W. Łysiak, Stulecie kłamców, Warszawa-Chicago 2000, s. 11.

17 Ibidem, s. 13.
} 
państwa i jego obywateli - wskaźnik postępu etyczno-moralnego, zrozumienia istoty i wyjątkowości fenomenu człowieka oraz odpowiedzialności za jego los.

\section{LITERATURA}

1. Furmanek W., Zarys humanistycznej teorii pracy (nowe horyzonty pedagogiki pracy), Wydawnictwo IBE, Warszawa 2006.

2. Heller M., Wszechświat jest tylko droga. Kosmiczne rekolekcje, Wydawnictwo Znak, Kraków 2012.

3. Jakubczak M., Cielesna tożsamość człowieka współczesnego. Sztuka Leczenia, 4 (1999), s.83-89; cyt. za Psychologia zdrowia w poszukiwaniu pozytywnych inspiracji, red. I. Heszen, J. Życińska,Wydawnictwo Szkoły Wyższej Psychologii Społecznej „Academica”, Warszawa 2008.

4. Kowalik S., Ja-cielesne - próba nowego spojrzenia. „Polskie Forum Psychologiczne”, 8 (2003), 1-2 cyt. za Psychologia zdrowia w poszukiwaniu pozytywnych inspiracji, Wydawnictwo Szkoły Wyższej Psychologii Społecznej „Academica”, Warszawa 2008.

5. Kubacka-Jasiecka D., Ja cielesne i problematyka identyfikacji z ciałem w kontekśsie wartości wspótczesnej kultury i zdrowia [w:] Psychologia zdrowia w poszukiwaniu pozytywnych inspiracji, red. I. Heszen, J. Życińska, Wydawnictwo Szkoły Wyższej Psychologii Społecznej „Academica”, Warszawa 2008.

6. Łysiak W., Stulecie kłamców, Wydawnictwo Andrzej Frukacz, EX LIBRIS, Warszawa-Chicago 2000.

7. Podolski A., Przywrócić sens cierpienia i godność cierpiacego [w:] Święty Jan Pawet II pierwszy doktor honoris causa Uniwersytetu rzeszowskiego, red. ks. S. Nabywaniec, Wydawnictwo Uniwersytetu Rzeszowskiego, Rzeszów 2015.

\section{GLOBALISATION OF CULTURE - THE REFLECTIONS ABOUT THE QUALITY OF LIFE OF THE DISABLED PEOPLE}

One of the positive consequences of globalisation of the culture might be the popularisation of the newest achievements of science and technology among different social groups. The disabled people are one of the social groups that are at risk of being marginalised. The benefits that these people may experience is not only the possibility of getting the professional and specialised health care in health centres, hospitals, and physiotherapeutic offices, but also full participation in social life through education, occupation, and fighting against popular stereotypes relating to the place and a role in society of the disabled people. Globalisation, despite many negative opinions, is a chance to popularise the ideals of moralism and Christian humanism according to which, every person is an exceptional being, whose life has a unique value.

Cultural globalization leads to the rapid spread of many phenomena which are dangerous for societies, especially, for people with disabilities. The above phenomena include setting store by appearance, body shape, beauty, clothes, fashion; neglect of human suffering, disappearing of solidarity of non-disabled people with disabled ones to overcome everyday life challenges; living in the environment of disability prejudice stereotypes, domination of everyday life orientation regarding to "have" over "to be someone". The unemployment and education of the disabled are considered to be the main problems, and at the same time, the challenges for many countries in the world. Despite the efforts undertaken by national governments, the situation is not yet satisfactory. People with disabilities nowadays have the lowest education 
achievements. Therefore, in the era of widespread computerization and highly advanced technologies they have little chance in the labor market. Unemployment is an important reason for the deterioration in the lifestyle factors, it leads to poverty.

Keywords: the quality of life, disability, society, globalization.

DOI: $10.7862 /$ rz.2018.hss.9

Przestano do redakcji: styczeń $2018 r$.

Przyjęto do druku: kwiecień 2018 r. 